\title{
An Anthropological View on the Taboo Incest as a Mean for Maintaining Social and Family Order
}

\author{
Rachel Sharaby \\ Department of Sociology, Ashkelon Academic College, Ashkelon, Israel \\ Email: rsharaby@gmail.com
}

How to cite this paper: Sharaby, R. (2019). An Anthropological View on the Taboo Incest as a Mean for Maintaining Social and Family Order. Advances in Anthropology, 9, 169-189.

https://doi.org/10.4236/aa.2019.94012

Received: August 25, 2019

Accepted: October 18, 2019

Published: October 21, 2019

Copyright $\odot 2019$ by author(s) and Scientific Research Publishing Inc. This work is licensed under the Creative Commons Attribution International License (CC BY 4.0).

http://creativecommons.org/licenses/by/4.0/

(c) (i) Open Access

\begin{abstract}
Incest was and is a universal taboo in human society. It is stigmatized as a deviation and leads to sanctions, in particular when minors are involved. Oral and written stories and narratives are stories that interpret and shape reality through the prism of power relations in society. In the present study, I carried out narrative analysis of incest stories in Hebrew Bible texts, those primordial stories and myths that shaped human society today. The article shows that incest was taboo from the onset, and is one of the seven Noahide laws. However, the social order was undermined already after the story of Creation: consanguineous marriages; sexual relations between a son and his stepmother, between a father and his daughters, and between a father and his daughter-in-law. The analysis shows that the brevity and ambiguity that characterize the Hebrew Bible "invited" interpretations and legends which biblical sages wrote over the generations. As a result, the text became part of a dynamic unit that forms new creations out of dialogue with the Book. Furthermore, the text is expropriated from the time axis and also serves as a relevant cultural work today. The feminist interpretation that attributes an important position to the reader enables reading that serves the feminist ideology and turns attention to subversive possibilities.
\end{abstract}

\section{Keywords}

Taboo, Sexual Abuse of Children, Culture, Narrative, Biblical Text, Feminist Interpretation

\section{Introduction}

Incest (in Latin incestum/incestus, meaning impure, immodest) is a term that describes consanguineous sexual relations forbidden by a particular society's law: between a father and his daughter or son, between a mother and her daughter or son, between a brother and a sister, etc. (Stiebert, 2016: pp. 1-18). The 
prohibition of incest is a universal taboo that is deeply imprinted in legal, religious and moral traditions in the past and in the present, and is stigmatized as a deviation that leads to grave sanctions (Wolf, 2017).

However, the term incest is also culturally relative, and different attitudes toward it can be found according to the period, the place and the cultural values. The definitions that refer to kinship relations that are forbidden from having sexual relations therefore differ from one society to another. The most common prohibition is incest between first-degree blood relatives: between a biological parent and a child, or between siblings. The prohibition of marriage between these relatives is also derived from this, contrary to consanguineous marriages that were not forbidden and were rather common. In Catholic Christianity, it is forbidden to marry relatives up to the seventh degree. However, in Judaism and Islam it is permissible to marry some second-degree relatives, for example cousins (Stiebert, 2016: pp. 1-18; Turner, Jonathan, \& Maryanski, 2015).

In ancient Chinese culture, incest was not equal to intimate intercourse, because incest was also found in ancient Chinese culture, such as the killing of father by son and the marriage of master and apprentice. In ancient China, incest was considered an act that exposes the father, the mother and the offspring to terrible disasters (for example, multiple tragic deaths in the family) and was forbidden, particularly to the royalty. In spite of the taboo, cases of incest occurred in the royal court (Enoch, 2000: p. 108). Studies indicate that incest also occurred in the royal courts of Egypt during the Hellenistic and Roman period as well as in ancient Persia. In these places, reproduction between brother and sister was forced, in order to preserve the purity of the royal dynasty (Hopkins, 1980; Wolf, 2017).

Greek mythology contains quite a number of incest stories. The most famous is the tragic story of Oedipus the King, about inadvertent incest between a mother and her son. The story ends in disaster, where Oedipus is punished for this act and gouges out his eyes. He goes into exile with his two daughters, and his wife-mother commits suicide.

Since the Middle Ages, incestual marriages also took place in the royal families of ancient Japan and Korea, among the Inca in Peru, in ancient Hawaii, and at certain times also in Central Africa, Mexico and Thailand (Dobbs, 2010). The rulers of the Inca also customarily married their sisters (Sarmiento de Gamboa, 2007: p. 171).

Today, laws forbidding incest which restrict consanguineous marriages exist in most modern societies (Bittles, 2012: pp. 178-187). However, the punishment for first-degree incest in the West is variable, and is far from universal (Stiebert, 2016: pp. 1-18). In the United States, incest is forbidden in all states, except for Rhode Island. However, the Penal Code of Ohio refers only to parental figures. In New Jersey there is no punishment if the parties are older than eighteen and sex was consensual.

When first-degree sexual relations occur between adults, especially between a brother and a sister, it is looked upon with some forgiveness. Thus, in Israel, the 
Ivory Coast and Turkey there is no punishment for this act. However, in Hong Kong the punishment is imprisonment of up to twenty years for a man and fourteen years for a women. In New Zealand, incest refers to parents, grandparents, siblings and half-siblings, whereas in Britain the prohibition is broader and includes adoptive and step parents, uncles and aunts, nieces and nephews. In Sweden, marriage between half-siblings is permitted (Rosman, Rubel, \& Weisgrau, 2009; Stiebert, 2016: pp. 1-18).

The conspiracy of silence, which is an integral part of the phenomenon, makes it difficult to estimate its scope. In the late $19^{\text {th }}$ century, Sigmund Freud claimed that the prevalence of the phenomenon in the population is one per million. Since then, and until the late 1970s, public disregard of the phenomenon of incest continued, a disregard that was accompanied by an absence of suitable legal interest (Etzioni, 2010: pp. 79-80).

However, researchers indicate the great prevalence of incest and the increase in awareness of this phenomenon in the past decade (Etzioni, 2010: p. 81; Stiebert, 2016: pp. 1-18). In their opinion, two main factors influenced this change in attitude. One is the change in the status of the victim (mainly child sexual abuse) in the criminal process, that was created on a background of changes in the status of the child and basic and human rights laws. The second is the changes that have taken place in women's status and the contribution of the feminist movement.

Incest is a kind of rape within the family. However, contrary to rape by a stranger, the sexual abuse in incest is possible not only by the use of force, but rather also by the authority and trust found in the hands of the abuser, and due to the helplessness of the child (Greydanus \& Merrick, 2017; Seligman \& Solomon, 2004). This abuse causes a severe and ongoing trauma, particularly in incest perpetrated by one of the parents. It is difficult to assess the prevalence of such cases, due to the secrecy involved in this issue (Ambrosio, 2018; Herman, 2012).

The most common reported type of incest is of father-daughter or step-father step-daughter (Herman, 2012; Kinnear, 2007). There are also cases of mother-son, father-son and mother-daughter, but they are less common (Shakeshaft, 2004; Watkins \& Bentovim, 1992). Incest between siblings during childhood, in particular between older and younger siblings, is considered to be common but is only rarely reported (Carlson, MacIol, \& Schneider, 2006; Morrill, 2014). It has been reported that inhibiting factors (sense of guilt, helplessness, loyalty to the family, etc.) and supporting factors (difficulty of carrying the burden of the secret, care for other children who may be hurt, extensive media coverage, etc.) exist among victims of sexual abuse in childhood (Seligman \& Solomon, 2004; Szwarcberg, 2001).

\subsection{Explanations for the Incest Taboo}

Researchers from different disciplines suggested diverse explanations for the taboo and its universality in human society. The most common explanation is ge- 
netic. Researchers claimed that children born as a result of sexual relations between relatives are at increased risk for genetic diseases. The reason for this is the similarity in the genetic charge of relatives, which increases with the increase in the kinship (Baird \& McGillivray, 1982; Staal, 2017). For example, there is a high prevalence of genetic diseases in societies where marriages between cousins are common (Bittles, 2001; Wolf \& Durham, 2004). However, more current studies show that the outcomes are not conclusive (Ali Khan \& Mazhar, 2018; El Guindi, 2018).

The anthropologist Edvard Westermarck claimed that physical proximity in early childhood leads to mutual sexual revulsion. In his opinion, this revulsion is a result of a biological mechanism that plays an important developmental role in preventing genetic defects. According to Westermarck, this mechanism also develops among those who grew up in close proximity, even if they are not relatives (Simchai \& Shor, 2013: p. 106; Westermarck, 1981).

Many scholars adopted Westermarck's viewpoint (see for example Durham, 2005; Wolf, 2005). They supported the claim that sexual revulsion is the cause for the consolidation of the incest taboo (Bateson, 2005; Fessler \& Navarrete, 2004). Westermarck's theory has regained popularity in recent decades. Psychologists, sociologists and anthropologists grounded his ideas and elaborated on them (Fessler \& Navarrete, 2004; Wolf, 2005). Studies on children who grew up together in kibbutzim in Israel reinforce Westermarck's position (Shepher, 1983; Simchai \& Shor, 2013: p. 107).

Since the 1920s, the Freudian theory, which stressed the existence of sexual attraction in the family and the centrality of the social taboo on incest as a curbing factor, has become more influential (Freud, 1950). Freud tried to explain incest in the psychoanalytical theory of the unconscious. According to Freud, the son develops a desire for his mother, which he called the "Oedipus complex", that causes rivalry with the father. Freud claimed that the story of Oedipus expresses the desire of every son to marry his mother and kill his father, who is competing over the exclusiveness of the relationship with her. The daughter's desire for her father ("Electra complex) causes similar rivalry with the mother.

Freud believed that the Oedipus complex is the most important factor in determining sexual behavior. He claimed that these drives are so strong that they need to be suppressed, and that the passage of the child between the ages of two to five, i.e. from the Oedipal stage to the post-Oedipal stage, is essential for healthy human development. Freud claimed that by the time children reach the post-Oedipal stage, the incest taboo is very strongly imprinted in their psyche, and controls their sexual behavior (see also Ambrosio, 2018; Stav, 2010).

Contrary to the Freudian viewpoint, anthropology supplies a social-cultural explanation for the universal prohibition of incest. Under the influence of the Functional-Structural Theory, researchers such as Bronislaw Malinowski indicated the important role of the family in maintaining social order. According to Malinowski, incest holds a risk for bursting the hierarchic boundaries of the family structure, thus harming its function and social stability. The incest taboo 
is therefore intended to order the roles in the family, prevent sexual jealousy among its members and maintain harmony (Malinowski, 1927; Simchai \& Shor, 2013: p. 106; Turner et al., 2015).

The anthropologist Claude Levi-Strauss claimed that culture is influenced by deep social structures, of which people are not always aware. The anthropologist must therefore decode the deep structure that affords meaning to the culture (Hirsch, 2010). According to Levi-Strauss, the incest prohibition plays a key role in shaping human society. The prohibition prevents the family from functioning as an autarkic unit, since its members must go outside the family in order to have sexual relations and reproduce ("rule of exogamy"). Forcing exogamy creates a mechanism of exchange which merges different families, with the aim of developing social networks and responsibility between groups, and strengthens the social structure itself (Levi-Strauss, 1969).

This anthropological explanation indicates that the family structure and the social order derived from it are based on the daughter's moving to another family upon marriage. Exchanging the daughter creates alliances between families, which can lead to social and economic benefits. Therefore, the daughter is the repressed factor of establishing the patriarchal social order (Stav, 2010: pp. 72-73).

\subsection{Prohibition of Incest in Judaism}

The origin of the Hebrew expression "gilui arayot" is the prohibition of uncovering the nakedness, as it is written "No one is to approach any close relative to have sexual relations. I am the Lord" (Leviticus 18: 6). The word arayot originates from the word erya which means naked. Another word is erva, which also means the genitalia. The prohibition of incest in the Hebrew Bible is broader than the customary definition of incest, and includes prohibition of sexual relations with a married woman, a menstruating woman, homosexual relations and sex with animals.

\section{The Structure of the Arayot (Incest) Portion (Samet, 2004)}

This portion includes 30 of the verses in Leviticus, chapter 18. The portion opens with a speech of five verses, and ends with a warning speech of seven verses. These twelve framework verses and their style indicate the importance and graveness of the incest laws. This structure also accentuates the main incest prohibitions (Leviticus 18: 6-15).

Chapter 18 is divided into two almost equal parts. The first part, on which I will focus in this article, includes an introductory speech on the prohibition of incest with relatives. This part presents the large group of prohibitions, where "No one is to approach any close relative to have sexual relations. I am the Lord" (Leviticus 18: 6) is common to them. This is followed by a detailing of women who are the man's relatives. The content and scope of the prohibitions list indicate a "family" kinship unit that includes a father and a mother and their married children. Incest is forbidden for the man and the woman, but the prohibi- 
tions are directed toward the man, during the course of his entire life:

1) With the generation above him: his mother, his father's wife, his father's sister, his mother's sister, his father's brother's wife.

2) With his generation: his sister, his half-sister, his wife's sister (as long as his wife is still alive). Judaism allows marriage between cousins, an uncle and his niece, and step-siblings (Sanhedrin 76: 2).

3) With the generation below him: his daughter-in-law (his daughter is not mentioned).

4) With the second generation below him: his son's daughter and his daughter's daughter.

Some of the women in the list do not belong to the "family" but are forbidden because of consanguinity. The prohibitions thus express a mixture of criteria, of life together in the "family" and of consanguinity. The repeated explanations stress kinship as the source for the prohibition of sexual relations between them (Zvi-Gilat, 2018).

The second part of the incest portion contains a smaller number of additional incest prohibitions: with a married woman (according to Bible exegetes also an unmarried woman), with two sisters (for fear that they will hate each other), with a menstruating woman, with homosexuals and with animals.

There exist controversies regarding the generations range of incest. Maimonides is lenient and limits the prohibition of a man's marriage to his offspring only up to his great-granddaughters (Hilchot Ishut 1: 6). However, other Bible exegetes claim that the prohibition extends until the end of all generations (Shulchan Arukh, Even HaEzer 15: 12). I should indicate that among the Jewish communities in Ethiopia, it was forbidden to marry relatives up to seven generations. However, Ethiopian immigrants in Israel enable marrying relatives beginning with four generations (Sharaby, 2015).

The incest prohibitions are repeated in Leviticus, chapter 20. However, the prohibition of incest with two sisters, which was included in the previous list, is now absent. In Deuteronomy (27: 15-26), the Pentateuch refers to all incest transgressions for the third time, and contains curses for those who will transgress these prohibitions. Bible exegetes explained that the common element to these transgressions is that they are usually performed clandestinely, and law-abiding human society cannot supervise them. They are therefore under Divine Providence that places a curse on them (Drori, 2012).

\section{The Punishment}

Having sexual relations with a relative is one of the three gravest transgressions in the Pentateuch (together with murder and idol worship), for which the verdict is "Let him be killed rather than transgress". Thus, if you are forced to transgress them, it is preferable to die. The Pentateuch also forbids intimate closeness that may lead to incest (Leviticus 18: 6).

There are grave incest prohibitions for which the punishment is death by God's hands (such as incest with a brother, the father's sister, the mother's sister 
and the wife's sister). Other grave incest prohibitions carry the punishment of death by a court (such as incest with his wife's daughter while the wife is still alive, with his wife's mother). A person who transgresses inadvertently must bring a sacrifice to atone for his sins. When a person marries a woman with whom he had incestual relations, the marriage is not valid (Etzioni, 2010: pp. 76-78; Zvi-Gilat, 2018).

\section{Explanations for the Prohibition}

The Pentateuch views the family cell as the basis for the existence of the human race and a close environment that supports the person (Genesis 2: 25). Its existence obligates restraining the sexual activity in it. Maimonides wrote that the purpose of the incest prohibition is to abolish desire for sexual relations between a man and female relatives who live in the same house, a relationship that harms them, their confidence and the relationships in the family (Guide for the Perplexed, part C, chapter 49). Bible exegetes indicated that the sexual tension, which is also related to power relations and competition, harms the familial fabric.

The incest prohibition is also included in the Pentateuch within the framework of God's commandment to the People of Israel "Be holy-abstain from incest and from transgression" (Leviticus 19: 1-20). Holiness thus exists when people distance themselves from incest, and anyone who acts in this manner is holy. The Hebrew Bible stresses the uniqueness of the People of Israel compared to the Egyptians, Canaanites and ancient peoples who customarily performed acts of incest (Leviticus 18: 27). The Pentateuch warned that anyone who transgresses the prohibition of incest will lose his moral right to belong to the Land of Israel (Leviticus 18: 28).

Bible critics claim that ambiguity and contradictions are inherent in Hebrew Bible texts that tell or allude to matters related to first-degree incest (Stiebert, 2016: pp. 1-18). Feminist Bible research has also begun to develop, and feminist interpretations are today related to postmodern approaches that afford an important position to the subject, i.e. the reader. The reader is responsible for the interpretation he gives the text, and the expectation from feminist reading is an interpretation that will serve feminist ideology and will turn attention to subversive possibilities (Shemesh, 2010: p. 61).

\subsection{Narrative Analysis for Understanding Culture}

The concept of narrative has diverse definitions (Spector-Mersel, 2011: p. 64). They can be placed on a spectrum, where the restrictive definition of social linguistics according to which a narrative is a distinct discourse unit with a focused topic and organized on a time axis is at one end. Definitions of social and anthropological history, which view the narrative as a complete life story woven from parts of interviews, observations and documents are at the other end. The common definitions in psychology and sociology, that view narratives as prolonged reports on life within a context, that develop during the course of one or more 
interviews, are found in the middle of the spectrum (Riessman, 2008). In their attempt to integrate between the definitions, Smith and Sparkes (2009: p. 2) defined a narrative as "A complex genre which usually includes a point and figures, alongside a plot that connects events that unfold in a sequence over time and space, in order to supply a general explanation or outcome" (Spector-Mersel, 2011: p. 64).

According to Chase's (2005: p. 652) suggestion, a narrative, as a verbal product, can be oral or written, and be created during a field study, interview or spontaneous conversation between people. In each of these situations, the narrative can be a short and focused story about a particular event (such as a trauma) or about certain heroes, an expanded story on the life of the narrator or a significant and ongoing aspect of his life.

One of the main points of origin in the narrative approach is the perception that people are natural story tellers, and that stories embed meanings important to the individual and his culture. The narrative approach emphasizes the communication elements of stories, and enables the participants to choose and stress their life experiences according to their discretion (Jacobs-Kayam \& Lev-Wiesel, 2019). Through the story we can understand the world around us, the others and ourselves, and therefore the story has organizing power (Clandinin, 2007; Tuval-Mashiach, 2009).

The narrative is a story that interprets reality through a particular prism of culture and power relations in society. Similarly to the myth, it serves for the establishment and structuration of a meaningful reality, which derives a particular worldview (Tuval-Mashiach \& Spector-Mersel, 2010). The literary critic Hillis Miller (1990) claimed that we always need the same mythical story that encompasses a summary of the cultural ideology of the times. The story, which is repeated with minor changes, is intended to serve functions of preserving the existing state and its confirmation.

\section{Methodology}

In this article I will use content analysis, which is a qualitative research method for analyzing different texts, such as written text, sound, picture, video, digital. In this article I will analyze the text of the Hebrew Bible. Krippendorff (2013) referred to content analysis as a research technique whose goal is accurate description of data intended to enable reaching valid conclusions that can be reconstructed to their broad context.

The increased use of the narrative paradigm in different disciplines in recent decades has led to the view of research as a process of interpretation and of affording meaning. This is an active process that imparts the researcher and his products an influence on reality, and he becomes an actor in the social world. The narrative inquiry may even help in a therapeutic situation, since it reconstructs the relations between the narrator-therapist and listener-patient. In every story, both parties deal in representation of actions that took place in reality 
(Brooks, 1994; Smith \& Sparkes, 2009). Furthermore, the narrative and feminist research in the postmodern era have opened doors to interpretive approaches that challenge the hegemonic reading, which is imprinted in the traditional texts (Butler-Kisber, 2018).

I will present a narrative analysis of incest in Hebrew Bible texts, and will focus on the book of Genesis, which tells the story of the beginning of human society. My aim is to test first-degree sexual relations using these narratives, and the validity of the taboo: what are the sexual prohibitions, narratives and first-degree sexual issues that appear in the text. I will attempt to assess the manner in which the term incest indicates illegality and taboo through the descriptions and allusions that appear in the text.

Such an analysis may produce information on social and cultural values, anxieties and family stresses. I will include critical and feminist approaches that were developed in Bible studies. My goal is not to justify or denounce any phenomenon of incest, but rather to turn attention to the biblical values and the subversive possibilities embedded in reading the text. Before presenting narratives of incest in Genesis, I will present the characteristics of Hebrew Bible stories.

\section{Results and Discussion}

\subsection{Characteristics of Hebrew Bible Stories}

The Hebrew Bible stories were not written in order to supply historical information. Rather, they were intended to teach us a moral lesson. A literary analysis of the Hebrew Bible shows that it was written in different literary styles, the main ones being prose and poetry sections. The prose sections, which are called "the biblical story", seem to be regular stories. However, they have an orderly structure and special motifs, and each story has a message. Nonetheless, the meaning of the story is only seldom formulated explicitly, and the reader can actually only observe it by understanding the components of the story and the manner of their integration (Amit, 2009).

The lone story is an independent literary unit. It usually has a prominent beginning and end, and has its own nature in both the plot, the figures included in it and its style. Hebrew Bible stories have several major literary and artistic characteristics (Amit, 2000; Nitzan, 2002; Samet, 2005):

1) Short style: The story has few descriptions of the plot. There are usually no details on the life of the hero until his appearance (who is Abraham?), his thoughts, feelings, traits, appearance, or his family and social life. Every word is thus significant and important for the plot's progression (about Sarah it is written that she was beautiful, so that we will understand what happened to her in Egypt). The "missing" parts were filled with exegesis and legends about the Bible over the generations (Stein, 2013).

2) Time and space: The duration of the biblical story is usually short. Unity or consecutiveness usually exists in the story's dimensions of space and time, and 
the movements of the personages and their progress in time can be followed. However, two plots that occur in different places and in different times will sometimes be put together under one roof. The opposite is also possible, and an ongoing and complex plot which is consecutive in time and place is composed of several stories. In his description of the plot, the biblical author may thus move rapidly from place to place or make a "time jump", according to the needs of the plot.

3) A small number of figures: Generally only two-three heroes appear in the story. If there are additional heroes, the story is divided into acts, and two-three heroes appear in each one (for example, in the story of the meeting between Eliezer and Rebecca). This structure imparts a dramatic nature to the story. The main message of most Hebrew Bible stories is hidden in the actions of the figures and is transmitted through them and their sayings. Secondary figures appear alongside the main figures, and the story uses them to help shape the main figure.

4) The hero is a person who has both a good and an evil inclination: There are figures who underwent a transformation from good to evil or vice versa (Brosh, 2016). The Hebrew Bible describes the plot as it happened, without any attempt to embellish or justify the actions. The traits imparted to the biblical figures are not simply unique traits, but rather also general human traits. The figures personify different sides of human nature, and therefore have representative power and broad human meaning. They can fulfill their role within the world of the story and can also pave their way directly into the reader's heart.

5) Silence: The story's hero is silent in cases where we would expect to hear his voice (for example, what did Cain and Abel argue about before the murder?).

6) Restrained language: The events are described with great restraint, even when the event is tragic (Yocheved and Moses in the basket).

7) Providence: There are successes and failures in the hero's life (such as the story of Joseph). The message is that there is Divine Providence, and a person must not be proud or lose hope.

8) The guiding word: The story contains various clues, which are encoded via guiding words. A guiding word is a word, root or phrase that recurs along the story with prominent frequency, intentionally (in the story of Cain and Abel, the word brother appears seven times, in order to stress the gravity of the act).

9) The author's position is vague: The biblical story usually does not contain the author's opinion on the personality of the story's hero, and his moral character, traits and attributes are revealed by his speech and actions. The reader must therefore read the text over and over, in order to understand the trend and conceptual meaning encrypted in it (Grossman, 2015).

10) Repetitions: Some stories are repeated with almost no change, and sometimes artistic use of repetition is used, in a manner that does not enable ignoring the meaning of the differences between the repetitions (such as in the story of Joseph and Potiphar's wife, Shemesh, 2010). The deviation from a fixed pattern, from an accurate repetition, is a mean which the author uses to transmit a mes- 
sage that requires fine distinction.

\subsection{Narratives on Incest in the Hebrew Bible}

\section{During the Period of Adam and Noah}

The "seven Noahide laws" are seven moral Biblical commandments, which according to God's commandment are universally valid and obligate all humans for maintaining a normal society. Adam was commanded to uphold the first six, and Noah and his sons were commanded to uphold the seventh after the Flood (Etzioni, 2010: p. 78). The incest prohibition is included in the seven Noahide laws. However, the social order was undermined already just after the story of Creation.

According to the Talmud, Cain married his sister (who is not mentioned in the biblical text), because there were no other humans around, and this was necessary for existence of the world (Babylonian Talmud, Tractate Sanhedrin, p. 58: 2). The cosmic balance is later disrupted when it is told of the coupling between the sons of God and the daughters of man: "When human beings began to increase in number [reproduce] on the earth and daughters were born to them, the sons of God saw that the daughters of humans were beautiful, and they married any of them they chose... and also afterward-when the sons of God went to the daughters of humans and had children by them" (Genesis 6: 1-4). In gender terms, this story illustrates the hierarchy between men and women and the woman's clear inferiority, which was reflected already during the Creation: the woman was created from the man's rib (Genesis 2: 21).

God's declaration about "how great the wickedness of the human race had become on the earth, and that every inclination of the thoughts of the human heart was only evil all the time" (Genesis 6: 5) and that "all the people on earth had corrupted their ways" (Genesis 6: 12) leads to the Flood. The Flood thus came in response to incest and additional transgressions, and was intended to wipe those who corrupted the land from the face of the earth. The story of the Flood is a story of a renewed Creation. It emphasizes and arranges contrasts between fundamental concepts, such as life and death, culture and nature, femininity and masculinity (Stein, 2013).

However, a sexual transgression is insinuated immediately upon disembarking from Noah's ark. Noah's drunken nakedness was exposed to his youngest son Ham. He ran to tell his two older brothers, and they covered their father with a dress (facing backward). When Noah woke up and discovered this, he cursed his son (Genesis 9: 18-29). The biblical story is characterized by brevity, and does not tell the details. Biblical exegetes therefore tried to complete the story and explain that the transgression was that Ham saw his father's nakedness and raped him (Babylonian Talmud, Tractate Sanhedrin, 70: 1; Stein, 2013).

Consanguineous Marriages

Many cases of consanguineous marriages are described in the Hebrew Bible (Etzioni, 2010). The most famous of these are: Abraham married Sarah, who was 
his brother's daughter (Genesis 11: 39); Isaac married Rebecca who was the daughter of his cousin Bethuel; Jacob married Rachel and Leah, the daughters of Laban the Aramite, who were sisters (Genesis 29: 12-14, 18); Amram, the father of Moses and Aaron, married his cousin Yocheved (Exodus 6: 20), etc.

The biblical narratives that describe marriages of cousins show that they were a social norm and were not included in the list of incest prohibitions. Marriage with an aunt was forbidden after the Revelation at Sinai (Leviticus 18), but was permitted before that, within the framework of the seven Noahide laws. Incest with two sisters was also permitted before the Revelation at Sinai, which explains Jacob's marriage to Rachel and Leah (Samet, 2004).

Stiebert (2016: pp. 89-93), who discussed these and other biblical narratives in her book, claimed that the Bible sometimes avoided criticizing first-degree incest. In her opinion, contrary to the accepted standards of custom and decency, the marriages of the fathers were not always considered illegal. She also demonstrated, in the case of Leah and Rachel (who cooperated with each other so that both would marry Jacob), how sisters act together on sexual matters, in order to undermine patriarchal norms.

Incest with the Father's Wife

Stories about incest between a mother and a son do not appear in the Hebrew Bible. However, sexual relations between a son and a stepmother do appear. For example, Reuben slept with Bilhah, his father Jacob's concubine (Genesis 35: 22). Another case is King David's son Absalom, who slept with ten of his father's concubines on the roof of the royal house for all of Israel to see, in order to express his rebellion against his father (2 Samuel 16: 22). Such acts are explained in light of Freud's Oedipus complex, where the son who desires to marry his mother views his father as a rival and wants to kill him (Friedman, 2000).

It should be noted that it was not legally or normatively wrong to commit such incest before the incest prohibitions were publicized upon the Revelation at Sinai. Nonetheless, Jacob cursed Reuben that he would be erased from the Tribes of Israel (Genesis 49: 4). According to one opinion, Reuben was punished not because he slept with his father's concubine, but rather because he tried to inherit his father during his lifetime (Friedman, 2000). Regarding Absalom, because he transgressed the laws of the Pentateuch which forbid sexual relations with the father's wife, he was killed in battle.

Lot and his Daughters

The story of Lot's daughters (Genesis 19: 30-38) is the earliest story in the Hebrew writings on incest between fathers and daughters. Lot was Abraham's nephew. Following a dispute that occurred between his shepherds and his uncle's shepherds, Abraham suggested to Lot that they separate, and Lot chose to live in the city of Sodom. The people of Sodom were known as great evildoers, and God's angels came down into the city to see whether there is a chance that they would reform. The angels pretended to be people, and when darkness fell, after Lot had hosted them in his home, the townspeople surrounded the house and demanded that he give his guests over to them so that they could sexually 
abuse them (Genesis 19: 5).

Since for Lot, the value of receiving guests was paramount, he offered his two daughters to the people of Sodom instead (Genesis 18: 8). Luckily for Lot's daughters, the townspeople refused. They approached to break down the door, and in response the angels hit them with temporary blindness. In the meantime, the angels smuggled Lot, his wife and two daughters out of town. His wife looked back, contrary to instructions, and turned into a pillar of salt.

In the end, Lot and his daughters came to an isolated mountainous area, where they found a cave. Lot's daughters thought that they were the only people left in a world that was destroyed, and must therefore ensure the continuation of the human race. The older one suggested that they give their father wine, so as to sleep with him and have children. The older daughter slept with him on the first night, and the younger daughter (after being persuaded by her sister) slept with him on the second night. Lot, who was drunk, did not know that they slept with him. The daughters became pregnant from their father and gave birth to two sons: Moav and Ben-Ami, who are the fathers of the peoples of Moav and Amon.

This story centers around acts of incest. The reader is shocked, but the language of the text is factual, emotionless and lacks a judgmental attitude. This is characteristic of the biblical text. It is possible that the dry and brief report actually increases the sense of horror. It is also possible that the manner of reporting such a difficult situation tries to arouse the reader and leaves space for him to decide regarding the morality of the act.

A renewed reading of the text, and its completion by biblical exegetes and other writings (Midrashes), enables extracting the text's judgmental attitude towards the act of incest performed by Lot's daughters. Already after the first reading it is clear that the story of Lot's daughters is not an independent unit. Rather, it is a direct result of the destruction of Sodom and Gemorrah that was described just before. In order to understand the story of Lot and his daughters, it must be examined in the broader context of the destruction of Sodom and Gemorrah (Zahar, 2008).

Biblical exegetes regarded Lot's daughters positively. They stressed that they transgressed the taboo not because of lust, but because they thought that the world was destroyed and they must save it. They therefore described these deeds as virtuous. The exegetes even praised the initiative of the older daughter who hurried to act and encouraged her sister (Midrash Rabbah 51: 8).

In contradistinction, the exegetes denounce Lot and do not clear him of responsibility. Lot is described as one who caused his uncle Abraham great suffering when he chose to live in Sodom which was notorious for its sexual sins, and as someone who offered his daughters up for group rape. The exegetes also indicated that although it is written that Lot was drunk and was seemingly raped, he did know what happened to him on the first night to some extent, and in spite of that did not avoid getting drunk on the second day (Babylonian Talmud, 
Tractate Nazir 23).

Researchers claimed that the narrative of incest in psychoanalysis, in myth and in the actual world, almost always involves denial of the father's incestuous lust and places the blame for seduction on the daughter. In their opinion, the literary representation of Lot as passive denies the incestuous lust, absolves Lot of all responsibility for breaking the taboo and even turns him into a victim (Rank, 1992: pp. 301-303; Stav, 2010).

However, a feminist reading of the story of Lot's daughters enables viewing it as an expression of the daughters' attitude toward Lot. It is an expression of feminine activism and dominance, a story where the father is now the weak figure and the daughters are the strong figures who drive the narrative (see also Stiebert, 2016: pp. 1-18). The act of Lot's daughters can thus be read as a response to Lot's sin of offering up his daughters in Sodom for mass rape. The incest of Lot's daughters enables them to cease being victims. Such a reading directs the reader to read the entire story, from what takes place in the city of Sodom until the birth of the two sons, as a narrative whose message is: measure for measure (Stav, 2010: p. 77).

\section{Judah and Tamar}

From the literary point of view, the story of Judah and Tamar (Genesis 38) is a delineated and closed unit within the story of Joseph (Genesis 37). It moves the reader from the main plot that follows Joseph's fate from his father's house until his death in Egypt, to a secondary plot about the history of Judah's family. The story of Judah and Tamar is composed of four units (Amit, 2000, 2009).

The first unit (Genesis 38: 1-12) comprises a particularly long exposition, and prepares the ground for the development of the story's plot. This unit reports on Judah's marriage, the death of his firstborn Er, the refusal of his second son Onan to marry the widow Tamar, and his death by the hands of God because he broke the obligation of levirate marriage (the wife of a son who was born without children marries his brother in order to continue the brother's memory). After the death of both his sons, Judah, who was responsible for enforcing the levirate marriage law, was afraid to give his daughter-in-law to his third son. Judah sent Tamar to her father's home with the excuse "until Shelah grows up" (and will be able to fulfill the commandment of levirate marriage). Tamar's status, after being removed from her husband's family where she could have inheritance rights, was undermined, and she became penniless. Judah's wife, the daughter of Shua, died and the days of mourning ended.

The second unit (Genesis 38: 13-23) describes Tamar's act in detail and with explanations, from the stage of planning until its execution. When Tamar saw that Shelah grew up and she was not given to him as a wife, she took off her widow's clothes, covered her face and body with a veil and sat on the road to Timnah, where Judah sheared his sheep. The description obtained from the text contributes to perceiving her as a positive figure. This is not an act of prostitution. Rather, it is a one-time act intended to burst the circle of the social reality 
into which Judah forced her. Judah is also described in a positive manner, without any suspicion of incest, since he did not recognize Tamar. Tamar agreed to receive a young goat, but also demanded a pledge from his personal belongings, and after they had sexual relations, she went on her way.

The third unit (Genesis 38: 24-26) describes Judah's reaction when he is informed that Tamar is pregnant, and wants to have her executed. This reaction, similarly to the demonstration of control over her affairs and destiny up to now, presents the entire story from a feminist angle, which views all of Judah's actions as clear signs of patriarchal and inconsiderate behavior. Tamar took out the pledge and said: "I am pregnant by the man who owns these". Judah felt ashamed and admitted "She is more righteous than I."

The fourth unit (Genesis 38: 27-30) presents the end of the story in the birth of twins: Perez (who was among the ancestors of King David) and Zerah. The double blessing was given to Judah as compensation for having lost two of his sons (see also Petersen, 2004). This positive ending forces the reader to reexamine Judah's behavior and the story's messages. There is no doubt that Judah sinned in that he prevented the realization of a levirate marriage and actually deceived and abandoned Tamar. He thus transgressed (albeit inadvertently) the prohibition of incest. However, the story transmits a message that a person like him, who suffered family tragedies, degraded himself publicly, confessed his mistake and repented, will be presented in a positive light and will be awarded a good ending (Amit, 2000).

This ending is also intended to persuade the reader that there is Divine Providence. It directs the reader to examine things beyond their specific framework, into a broader context that will expose God's winding and unexpected ways. Inclusion of the story of Judah and Tamar within the framework of the story of Joseph illustrates Judah's central position in the realization of the Divine Plan: without Judah, who served as an instrument in the hands of Providence, and succeeded in persuading his brothers to exchange killing Joseph with selling him, Joseph would not have achieved his status in Egypt and in the future lives of the People of Israel (Amit, 2000).

From a feminist comparative perspective, Judah's daughter-in-law Tamar, similarly to the story of Lot's daughters, concealed her identity and disguised herself so that Judah would sleep with her. These cases include deception. However, they are not considered rape. Lot and Judah had sexual relations with the women consensually, even though they were deceived.

Tamar was indeed a victim of circumstances, but had great courage to fight them. In light of the helplessness that Judah, head of the patriarchal family, exhibited, it was she, the weak link in the family, who demonstrated resourcefulness. In a smart and bold act, she saved not only herself from the fate of a lonely widow, but also Judah's family. Such a perception turns Tamar's act into de-patriarchalization of the biblical text, i.e. its liberation from the patriarchic level (Trible, 1976). This liberation exposes other voices in the text, that place the woman in a position of full or partial equality to the man (Meyers, 2008). 


\section{Conclusion}

Incest is a universal taboo in human society, in the past and in the present. The definitions that refer to kinship relations which are forbidden to have sexual relations differ from one society to the next, but in most of them sexual relations between parents and their children and between siblings are forbidden. The taboo is deeply imprinted in the legal, religious and moral traditions of countries, and continues to be valid in spite of the increasing exposure of information on cases of incest. Such acts are labeled as a deviation and lead to sanctions, especially when the children are minors.

Researchers from different disciplines suggested genetic, psychological and social explanations for the incest taboo and its universalism in human society. The Hebrew Bible is also part of the discourse on incest, and the prohibition in it is broader than the customary definition of incest. Consanguineous sexual relations are a grave prohibition in the Pentateuch, and the punishment for it is death by the hands of God or a court. The Pentateuch even forbids close proximity that may lead to incest.

In this article I performed a narrative analysis of incest in the text of the book of Genesis, which tells the story of the beginnings of human society. Since the narrative is a story that interprets reality through a particular prism of culture and power relations in society, I tested the expressions and validity of the taboo in the Hebrew Bible through narratives of first-degree sexual relations.

I found that incest was taboo already at the beginning of human society and is included in the seven Noahide laws. However, immediately after the story of Creation, the social order was undermined. The Hebrew Bible also describes many cases of consanguineous marriages (Jacob married the sisters Rachel and Leah; Amram, the father of Moses, married Yocheved his aunt; etc.). Some were forbidden after the Revelation at Sinai, but were permitted prior to this, within the framework of the seven Noahide laws. Stories on sexual relations between a son and a stepmother appeared in the Hebrew Bible (Reuben with Bilhah, his father's concubine; Absalom with his father David's concubines). Additional narratives dealt in incest between a father and his daughters (Lot and his two daughters) and between a father and his daughter-in-law (Judah and Tamar).

From the analysis of the above-presented narratives on incest, I conclude that the brevity and ambiguity that are typical of biblical texts "invited" interpretations and legends that were written by biblical sages over the generations. The fertile imagination of artists also filled the gap in the biblical stories through poems and plays, paintings, sculptures, music and theater.

The Hebrew Bible text is converted into part of a broader dynamic unit called a "contexture" via the exegetic and artistic works (Weiss, 2008), and creates new works out of direct and indirect dialogue with the book and its numerous products. The text is expropriated from the time axis and therefore serves as a foundation for cultural creations that are relevant today as well. Current feminist interpretation, which is related to postmodern approaches, also affords an impor- 
tant place to the reader. It therefore enables reading that serves feminist ideology, and turns the gaze toward subversive possibilities (Shemesh, 2010: p. 61).

A final comment regarding current anthropological research of incest. Since the phenomenon is well concealed within the boundaries of the family and the community, it is clear that the challenge facing anthropological researchers is more complex than that facing researchers from therapeutic disciplines, such as social work, criminology, psychology-psychiatry, who examine the issue through narratives of victims or abusers.

Nonetheless, in light of the numerous changes that have taken place in the status of the family and its forms in recent decades, as well as the legitimization of diverse forms of couplehood that blur the relations in the family, including sexual relations (Bar-Yosef, 2007), anthropological research is essential for supplying new definitions and explanations for a changing cultural reality. In the present study, I showed that even in ancient biblical times, the definitions and interpretations of incest were not unequivocal. Furthermore, even in the ancient extremely patriarchal society, the Hebrew Bible text can be interpreted in different ways.

As mentioned, one of the features of the Hebrew Bible text is brevity. As a result, there exist numerous interpretations, myths, legends, etc. It is therefore difficult to determine the precise anthropological reality that existed during this period.

\section{Limitations}

As mentioned, one of the features of the Hebrew Bible text is brevity. As a result, there exist numerous interpretations, myths, legends, etc. It is therefore difficult to determine the precise anthropological reality that existed during this period.

\section{Acknowledgements}

This article was supported by the Research Committee of the Ashkelon Academic College, Israel.

\section{Conflicts of Interest}

The author declares no conflicts of interest regarding the publication of this paper.

\section{References}

Ali Khan, F. Z., \& Mazhar, S. B. (2018). Current Trends of Consanguineous Marriages and Its Association with Socio-Demographic Variables in Pakistan. International Journal of Reproduction, Contraception, Obstetrics and Gynecology, 7, 1699-1705. https://doi.org/10.18203/2320-1770.ijrcog20181898

Ambrosio, G. (2018). On Incest: Psychoanalytic Perspectives. London: Routledge. https://doi.org/10.4324/9780429477966

Amit, Y. (2000). Likro Sipur Mikrai (To Read a Biblical Story). Tel-Aviv: Ministry of Defense (Hebrew). 
Amit, Y. (2009). Narrative Analysis: Meaning, Context and Origins of Genesis. In J. M. LeMon, \& K. H. Richards (Eds.), Method Matters: Essays on the Interpretation of the Hebrew Bible (pp. 271-291). Atlanta, GA: Society of Biblical Literature.

Baird, P. A., \& McGillivray, B. (1982). Children of Incest. The Journal of Pediatrics, 101, 854-857. https://doi.org/10.1016/S0022-3476(82)80347-8

Bar-Yosef, R. (2007). Sociologia Shel Ha'misphacha le'or Shinuyim Chevratiim Ve'chidushim Biotechnologim (Sociology of the Family in Light of Social Changes and Biotechnological Innovations). In M. Adar-Bunis (Ed.), Mishpachot Be'reiya Sociologit Ve'antripologit [Families from a Sociological and Anthropological Viewpoint] (pp. 255-279). Raanana: The Open University. (Hebrew)

Bateson, P. (2005). Inbreeding Avoidance and Incest Taboo. In A. P. Wolf, \& H. Durham (Eds.), Inbreeding, Incest and the Incest Taboo (pp. 23-37). Stanford, CA: Stanford University Press.

Bittles A. H. (2001). A Background Summary of Consanguineous Marriage. Edith Cowen University, Joondalup: Centre for Human Genetics.

Bittles, A. H. (2012). Consanguinity in Context. Cambridge: Cambridge University Press. https://doi.org/10.1017/CBO9781139015844

Brooks, P. (1994). Psychoanalysis and Storytelling. Oxford, UK and Cambridge, MA: Blackwell.

Brosh, B. (2016). Dmut Transformatia shel Hamelech/Dmut Hamelech Hanehefecht (Transformation Figure of the King/Transforming Figure of the King). Beit Mikrah, 61, 31-73. (Hebrew)

Butler-Kisber, L. (2018). Qualitative Inquiry. Canada: McGill University.

Carlson, B. E., MacIol, K., \& Schneider, J. (2006). Sibling Incest: Reports from Forty-one Survivors. Journal of Child Sexual Abuse, 15, 19-34.

Chase, S. (2005). Narrative Inquiry. In N. Denzin, \& Y. Lincoln (Eds.), The Handbook of Qualitative Research (pp. 651-679). Thousand Oaks, CA: Sage.

Clandinin, D. J. (2007). Handbook of Narrative Inquiry. Thousand Oaks, CA: Sage.

Dobbs, D. (2010). The Risks and Rewards of Royal Incest. National Geographic Magazine, $218,1-60$.

Drori, M. (2012). Haonesh al Gilui Arayot Bemishpat Haivri Vebemishpat Hayisraeli (The Punishment for Incest in Jewish Law and in Israeli Law). In A. Hacohen, \& M. Vigoda (Eds.), Ki Tavoh Portion (Vol. 409). (Hebrew) http://www.daat.ac.il/mishpat-ivri/skirot/skira.asp?id=206

Durham, W. H. (2005). Assessing the Gaps in Westermarck's Theory. In A. P. Wolf, \& H. Durham (Eds.), Inbreeding, Incest and the Incest Taboo (pp. 121-138). Stanford, CA: Stanford University Press.

El Guindi, F. (2018). Properties of Kinship Structure: Transformational Dynamics of Suckling, Adoption and Incest. In W. Shapiro (Ed.), Focality and Extension in Kinship (pp.177-201). Canberra, Australia: Australian National University Press. https://doi.org/10.22459/FEK.04.2018.05

Enoch, Y. (2000). Mavo Le'sociologia (Introduction to Sociology). Tel-Aviv: The Open University.

Etzioni, L. (2010). Haim Ha'psichologia Yechola Le’shamesh Ke“Mekadem Hagana"? (Can Psychology Serve as "Promoting Protection"?) Shaarei Mishpat, 5, 71-130. (Hebrew)

Fessler, D. M., \& Navarrete, D. C. (2004). Third-Party Attitudes toward Sibling Incest: 
Evidence for Westermarck's Hypothesis. Evolution and Human Behavior, 25, 277-294. https://doi.org/10.1016/j.evolhumbehav.2004.05.004

Freud, S. (1950). Totem and Taboo. New York: Norton.

Friedman, D. (2000). Ha'razachta Vegam Yarashta: Mishpat, Musar Ve'chevra Be'sipurei Ha'mikra (You Have Both Murdered and Inherited: Law, Morality and Society in the Biblical Stories). Tel-Aviv: Dvir. (Hebrew)

Greydanus, D. E., \& Merrick, J. (2017). Incest: Child Sexual Abuse within the Family. International Journal of Child and Adolescent Health, 10, 275-284.

Grossman, J. (2015). Galui Vemutzpan (Overt and Hidden). Tel-Aviv: Hakibbutz Hameuchad. (Hebrew)

Herman, J. L. (2012). Father-Daughter Incest. Cambridge, MA: Harvard University Press. https://doi.org/10.2307/j.ctvjnrv84

Hirsch, D. (2010). Claude Lévi-Strauss. In N. Gertz (Ed.), Teoriyot Ve'gishot Bechker Ha'tarbut (Theories and Approaches in Culture Research) (pp. 71-74). Raanana: The Open University. (Hebrew)

Hopkins, K. (1980). Brother-Sister Marriage in Roman Egypt. Comparative Studies in Society and History, 22, 303-354. https://doi.org/10.1017/S0010417500009385

Jacobs-Kayam, A., \& Lev-Wiesel, R. (2019). In Limbo: Time Perspective and Memory Deficit among Female Survivors of Sexual Abuse. Frontiers in Psychology, 10, 1-13. https://doi.org/10.3389/fpsyg.2019.00912

Kinnear, K. (2007). Childhood Sexual Abuse. New York: ABC-Clio.

Krippendorff, K. (2013). Content Analysis. An Introduction to Its Methodology(3rd ed.). Thousand Oaks, CA: Sage.

Levi-Strauss, C. (1969). The Elementary Structures of Kinship. Boston, MA: Beacon Press. Malinowski, B. (1927). Sex and Repression in Savage Society. London: Harcourt Brace.

Meyers, C. (2008). Women in Ancient Israel-An Overview. In T. Cohn Eskenazi, \& A. L. Weiss (Eds.), The Torah: A Women's Commentary (pp. 41-47). New York: Women of Reform Judaism URJ Press.

Miller, H. (1990). Narrative. In F. Lentricchia, \& T. McLaughlin (Eds.), Critical Terms of Literary Studies. Chicago, IL: Chicago University Press.

Morrill, M. (2014). Sibling Sexual Abuse: An Exploratory Study of Long-Term Consequences for Self-Esteem and Counseling Considerations. Journal of Family Violence, 29, 205-213. https://doi.org/10.1007/s10896-013-9571-4

Nitzan, J. (2002). Segulot Ha'sipur Ha'mikrai (Attributes of the Biblical Story). Morashtenu, 15, 153-165. (Hebrew)

Petersen, J. (2004). Reading Women's Stories. Minneapolis, MN: Fortress Press.

Rank, O. (1992). The Incest Theme in Literature and Legend. Baltimore, MD: Johns Hopkins University Press.

Riessman, C. K. (2008). Narrative Methods for the Human Sciences. Thousand Oaks, CA: Sage.

Rosman, A., Rubel, P., \& Weisgrau, M. (2009). The Tapestry of Culture: An Introduction to Cultural Anthropology. Plymouth, UK: AltaMira Press.

Samet, E. (2004). Iyunim Be'parshat Ha'shavua (Studies of the Weekly Portion) (Vol. 2). Jerusalem: Ma'alot. (Hebrew)

Samet, E. (2005). Encyclopedia Yehudit Daat-Hasipur Ha'mikrai; Iyunim Be'parshat Ha'shavua (Jewish Encycolopedia Daat-the Biblical Story; Studies of the Weekly Por- 
tion) (Hebrew).

http://www.daat.ac.il/he-il/tanach/parashat-shavua/\%D7\%A2\%D7\%99\%D7\%95\%D7\% A0\%D7\%99\%D7\%9D-\%D7\%91\%D7\%A4\%D7\%A8\%D7\%A9\%D7\%AA-\%D7\%94\%D7 \%A9\%D7\%91\%D7\%95\%D7\%A2-\%D7\%94\%D7\%A8\%D7\%91-\%D7\%90\%D7\%9C\%D7 \%97\%D7\%A0\%D7\%9F-\%D7\%A1\%D7\%9E\%D7\%98-\%D7\%A1\%D7\%93\%D7\%A8\%D7 \%94-\%D7\%A9\%D7\%A0\%D7\%99\%D7\%94

Sarmiento de Gamboa, P. (2007). The History of the Incas. Austin, TX: University of Texas Press.

Seligman, Z., \& Solomon, Z. (2004). Hasod Veshivro: Sugiot Begilui Arayot (The Secret and Its Shattering: Problems in Incest). Tel-Aviv: Hakibbutz Hameuchad. (Hebrew)

Shakeshaft, C. (2004). Educator Sexual Misconduct: A Synthesis of the Literature (p. 22). Boston, MA: US Department of Education.

Sharaby, R. (2015). Familial Aspects in the Marriage Rites of Ethiopian Jews. Peamim, 141, 105-137. (Hebrew)

Shemesh, Y. (2010). Eina Reuya Le'hagana: Eshet Potiphar, Heker Ha'mikrai Ve'hahakira Ha'feministit (Not Worthy of Defending: Potiphar's Wife, Biblical Research and the Feminist Investigation). Beit Mikrah, 55, 46-76. (Hebrew)

Shepher, J. (1983). Male Election among Second-Generation Kibbutz Adolescents and Adults: Incest Avoidance and Negative Imprinting. Archives of Sexual Behavior, 1, 293-307. https://doi.org/10.1007/BF01638058

Simchai, D., \& Shor, E. (2013). Arayot Ve'nemerim Ba'kibutzim: Retia Minit Ve'meshicah Bekerev Yeladim Shegadlu Bebatei Megurim Ba'kibutzim (Lions and Tigers in the Kibbutz: Sexual Deterrence and Attraction among Children Who Grew up in Living Quarters in the Kibbutz). Megamot, 49, 106-133. (Hebrew)

Smith, B., \& Sparkes, A. (2009). Narrative Inquiry in Sport and Exercise Psychology: What Can It Mean, and Why Might We Do It. Psychology of Sport and Exercise, 10, 1-11. https://doi.org/10.1016/j.psychsport.2008.01.004

Spector-Mersel, G. (2011). Hamechkar Hanarativi Keparadigmat Mechkar Parshanit (Narrative Research as an Interpretive Research Paradigm). Shevilei Mechkar, 17, 63-72. (Hebrew)

Staal, J. (2017). Applied Cultural and Social Studies Are Needed for a Sustainable Reduction of Genetic Disease Incidence. European Journal of Sociology and Anthropology, 2, 1-10. https://doi.org/10.20897/ejsa.201701

Stav, S. (2010). Avot Vebanot: Hamilkud Shel Gilui Arayot (Fathers and Daughters: The Entrapment of Incest). Teoriya Vebikoret, 37, 69-95. (Hebrew)

Stein, D. (2013). Noach, Mishpachto Ve'chayot Acherot: Ha'midrash, Ha'sifrut Ha'amamit Ve'parshanut Ha'sipur Ha'mikrai (Noah, His Family and Other Animals: The Midrash, the Folk Literature and Exegesis of the Biblical Story). Mechkarei Yerushalayim Be'sifrut Ivrit, 25, 87-105. (Hebrew)

Stiebert, J. (2016). First-Degree Incest and the Hebrew Bible: Sex in the Family. London: Bloomsbury T\&T Clark.

Szwarcberg, S. (2001). Variables in Delayed Disclosure of Child Sexual Abuse. American Journal of Orthopsychiatry, 71, 332-341. https://doi.org/10.1037/0002-9432.71.3.332

Trible, P. (1976). Depatriarchalizing in Biblical Interpretation. In E. Koltun (Ed.), The Jewish Woman: New Perspectives (pp. 217-240). New York: Schodken Books.

Turner, J., Jonathan H., \& Maryanski, A. (2015). Incest, Origins of the Taboo. New York: Routledge. https://doi.org/10.4324/9781315633985

Tuval-Mashiach, R. (2009). Sub Text Ve'context: Mabat Narativi al Dialog (Sub-Text and 
Context: Narrative View of Dialogue). Analiza Irgunit, 14, 7-16. (Hebrew)

Tuval-Mashiach, R., \& Spector-Mersel, G. (2010). Mechkar Narativi (Narrative Research). Jerusalem: Magnes. (Hebrew)

Watkins, B., \& Bentovim, A. (1992). The Sexual Abuse of Male Children and Adolescents: A Review of Current Research. Journal of Clinical Psychology and Psychiatry, 33, 197-248. https://doi.org/10.1111/j.1469-7610.1992.tb00862.x

Weiss, Z. (2008). Limud Ha'mikra Ke'i Havana (Learning the Bible as a Misunderstanding). Hagut, 8, 141-163. (Hebrew)

Westermarck, E. (1981). The History of Human Marriage. London: Macmillan.

Wolf, A. P. (2005). Introduction. In A. P. Wolf \& H. Durham (Eds.), Inbreeding, Incest and the Incest Taboo (pp. 1-23). Stanford, CA: Stanford University Press.

Wolf, A. P. (2017). Incest Avoidance and the Incest Taboos, Two Aspects of Human Nature. Sexuality and Culture, 21, 323-329. https://doi.org/10.1007/s12119-015-9327-9

Wolf, A. P., \& Durham, W. H. (2004). Inbreeding, Incest and the Incest Taboo: The State of Knowledge at the Turn of the Century. Stanford, CA: Stanford University Press.

Zahar, Y. (2008). Bnot Lot (Lot's Daughters). Telalei Orot, 14, 63-72. (Hebrew)

Zvi-Gilat, I. (2018). Rov Beilot Achar Ha’baal Be’halacha Yehudit-Atzimat Eynayim oh Re'iya Mefukachat (Most Intercourses after the Husband in Jewish Halakha-Turning a Blind Eye or Sound Viewpoint). In A. Gottlieb (Ed.), Olamot Nifgashim (Meeting of Worlds) (pp. 249-266). Ramat Gan: Bar-Ilan University. (Hebrew) 